BOOK REVIEW

HIGHLIGHTING MALE RAPE: RESEARCHING SENSITIVE, STIGMATIZED, AND TABOO TOPICS

Ben Colliver

Birmingham City University

\title{
Male Rape, Masculinities, and Sexualities: Understanding, Policing, and Overcoming Male Sexual Victimisation
}

By Aliraza Javaid (Palgrave Macmillan, 2018)

Male Rape, Masculinities, and Sexualities is an attempt address a significant gap in existing literature on the important topic of male rape. Author Aliraza Javaid does this by drawing upon data collected through qualitative interviews and surveys of 70 police officers, male rape counsellors, therapists, and voluntary agency case-workers. Javaid solidifies our current understanding of male rape, but also contributes a new perspective, by focusing upon the policing of and responses to male rape. Divided into eight chapters, the text challenges dominant heteronormative, gendered understandings of rape and highlights the important issue of male rape. The findings from Javaid's study are framed within some key pieces of existing literature, including Abdullah-Khan (2008), Jamel (2010), and Weiss (2010). This book also provides a critical analysis of existing literature within the United Kingdom, demonstrating the gendered nature of wider structural issues that influence the construction of rape as a crime only affecting women - a construction that perpetuates male rape myths. 
Two main theoretical perspectives guide the study. In addressing the intersections between male rape, gender and sexuality, the author draws on hegemonic masculinity and heteronormativity to frame these issues. Both of these frameworks are key to understanding the cultural and social constructions of male rape, and more specifically within the contexts of police and voluntary agencies. Javaid clearly argues that male rape undermines the victim's masculinity and legitimizes unequal power relationships between victim and perpetrator. However, the author also documents the ways in which victims may attempt to reclaim their masculinity through the use of alcohol and aggression.

The major strengths of this book are the author's ability to demonstrate the ways gender and sexuality intersect with male rape. The data illustrate how heteronormativity and stereotypical assumptions about gay men permeate police and voluntary organizations, strengthening members' belief in male rape myths. For example, one participant within this research claims that gay men "are promiscuous owing to their social lives and [are] adventurous sexually... This can... result in them putting themselves in vulnerable situations" (p. 172). It is clear to see here that male rape is being constructed as a "gay problem" in which harmful stereotypes regarding gay men are drawn upon to justify these conclusions. The myths are also perpetuated through their interactions with victims. As one voluntary agency case worker states, "it might not be taken seriously. It might be an inexperienced voluntary agency worker that is dealing with it and dismisses it and then not carrying the report through" (p. 242). Given the heteronormative society within which these organizations function, it is unsurprising to discover heteronormativity permeating throughout. Furthermore, the author pays significant attention to the "silent discourse" of male rape, which contributes to the notion that "men cannot be raped." In attending to this discourse, Javaid identifies the need for training for professionals to be more attentive to the 
complexities associated with male rape victimization. The author suggests practical strategies for improving responses to victims of male rape.

Additionally, the author pays significant attention to the topic of autoethnographic reflexivity. Issues of stigma are critically considered, along with the wider implications for a researcher's safety and well-being outside of the research process-including considerations to socializing and family relationships. This helps the reader understand the researcher's data collection and analysis. It also provides a detailed description for future researchers to consider when studying sensitive, stigmatized, or "taboo" topics, especially via autoethnography. This is a significant contribution that falls outside the main aims of the book.

However, Javaid's work is not without weaknesses. The author acknowledges the limitations of small sample sizes, yet there are times when he makes quite general, broad claims. I am not saying these claims are inaccurate or unsupported, but at times minimal data is used to illustrate a point.

Additionally, while Javaid acknowledges that gender, sexualities, and masculinities are fluid, contextual, and situational, the book's focus is on the ways in which the victim's masculinity is subordinated as a result of male rape and thus does not address how a victim's masculinity, and indeed heterosexuality, may be bolstered through enduring homosexual sex practices (Ward 2015). The literature exploring this primarily originates from the United States (which the author acknowledges is different culturally, socially, and politically from the United Kingdom), but it may have provided an interesting counter-perspective.

While there is a noteworthy body of literature exploring the sexual victimisation of women, this study makes a significant contribution to the emerging literature and research that addresses male rape. Male Rape, Masculinities, and Sexualities offers an alternative perspective to what is currently available, by exploring the issue from the perspective of 
police forces and voluntary agencies. The book makes advances our understanding of the ways in which male rape, gender, and sexuality intersect. Javaid clearly illustrates how male rape myths shape actors' beliefs and practices. In doing so, the author is able to critically assess the ways in which different masculinities are constructed and negotiated at different times and at different levels. Overall, this book is a timely and relevant publication that expands our understanding of male rape.

\section{REFERENCES}

Abdullah-Khan, Noreen. 2008. Male Rape: The Emergence of a Social and Legal Issue. Basingstoke, Hampshire: Palgrave Macmillan. Jamel, Joanna. 2010. "Researching the Provision of Service to Rape Victims by Specially Trained Police Officers: The Influence of Gender-An Exploratory Study." New Criminal Law Review: An International and Interdisciplinary Journal 13(4):688-709. Ward, Jane. 2015. Not Gay: Sex between Straight White Men. New York: NYU Press. Weiss, Karen G. 2010. “Male Sexual Victimisation: Examining Men’s Experiences of Rape and Sexual Assault." Men and Masculinities 12(3):275-298.

\section{ABOUT THE CONTRIBUTOR(S)}

Ben Colliver is a lecturer in Criminology at Birmingham City University. His research interests include hate crime, queer studies, gender, and sexuality. His most recent project focuses on "everyday" and "mundane" incidents of discrimination and hate crime targeting transgender and non-binary communities, with a specific interest in online interactions. He is a member of the steering group of the British Society of Criminology Hate Crime Network. 